\title{
Nelson Rodrigues, leitor e escritor: "diálogos”, criatividade e erudição explícita nas crônicas futebolísticas
}

CDD. 20.ed. 796.33

796.3309

http://dx.doi.org/10.1590/1807-55092014000300405
André Mendes CAPRARO*

Natasha SANTOS*
*Departamento de Educação Física, Universidade Federal do Paraná.

\section{Resumo}

0 objetivo da presente pesquisa é desvendar as interferências de outros gêneros trabalhados por Nelson Rodrigues, que teriam um vínculo menor com a verdade - especificamente o teatro -, nas construções sobre o futebol, edificadas na crônica esportiva do escritor. Atrelado a isso, intenta-se, ainda, expor o sentido com que Nelson utilizou tais recursos em seus textos futebolísticos, bem como as diversas influências a partir da leitura de clássicos da literatura nacional e mundial; ou até as nem sempre sutis referências a filósofos, sociólogos e mesmo os amigos intelectuais com quem dialogava. Para tal, contouse com a análise de crônicas e roteiro rodrigueanos, pautada no referencial de Antonio Candido, quanto ao tratamento da literatura enquanto fonte, segundo o qual se faz necessária a intersecção entre texto (autonomia do autor e fatores de arte), bem como contexto da obra.

Palavras-Chave: Futebol; Literatura; Intertextualidade; Crônica esportiva.

\section{Introdução}

O objetivo da presente pesquisa é desvendar as interferências de outros gêneros trabalhados por Nelson Rodrigues, que teriam um vínculo menor com a verdade - especificamente o teatro -, nas construçóes sobre o futebol, edificadas na crônica esportiva do escritor. Atrelado a isso, intenta-se, ainda, expor o sentido com que Nelson utilizou tais recursos em seus textos futebolísticos, bem como as diversas influências a partir da leitura de clássicos da literatura nacional e mundial; ou até as nem sempre sutis referências a filósofos, sociólogos e mesmo os amigos intelectuais com quem dialogava. Sob essa perspectiva, Nelson Rodrigues se utilizava de explanaçóes passionais, acompanhadas de uma estrutura estética deveras literária, as quais tornaram-se populares entre o público. A polêmica nos escritos do Anjo Pornográfico é constituída pela inversão das expectativas, ao afirmar o inesperado - o que justificaria a insistência no tratamento de assuntos morais e identitários, sob a perspectiva imoral e/ou submissa que Nelson Rodrigues costumava expor ${ }^{1}$.
Ora, no que se refere ao gênero crônica, de acordo com CANDIDO ${ }^{2}$, este seria definido como uma intersecção entre literatura, jornalismo e vida social e cotidiana, de caráter provisório, momentâneo. Tendo em vista que circula em jornais, a crônica aborda notícias do dia-a-dia, no intuito de atrair o leitor. Daí a sua efemeridade.

Por se tratar de um gênero presente no jornal, não é comum à estrutura da crônica o uso de personagens. Eis aqui, uma das maiores peculiaridades estilísticas de Nelson Rodrigues: o uso de personagens - ora reais, ora fictícias - em suas crônicas futebolísticas, assumindo a posição de um narrador-autor que trabalha de maneira fabular os acontecimentos esportivos ou sociais ${ }^{1}$. Ao acrescentar personagens na crônica esportiva, o dramaturgo estabelece teses e opinióes diretamente relacionadas a fatos do cotidiano, as quais, por mais paradoxal que pareça, eram mediadas, embasadas e justificadas por meio da criação literária. 


\section{Método}

Para atingir o objetivo proposto no presente texto, contou-se com a análise de crônicas rodrigueanas, presentes nas coletâneas A Pátria em Chuteiras, À Sombra das Chuteiras Imortais e O Profeta Tricolor, e o roteiro de $A$ Falecida, do mesmo autor, pautada no referencial de Antonio Candido, quanto ao tratamento da literatura enquanto fonte. É com base na intersecção de texto (autonomia do autor / estética literária) e contexto (elementos sociais), que o elemento social e histórico não deve ser considerado externamente à produção, mas como um aspecto externo que se torna interno à obra literária - daí a impossibilidade de se negar uma interpretação estética, já que esta assimila a dimensão histórica-social como fator de arte ${ }^{3}$.

Para CANDIDO ${ }^{3}$, a obra literária sofre influências do meio no qual o autor está inserido, isto é, ela dialoga diretamente com o lugar de onde o escritor fala, bem como com as influências pessoais deste. Assim, não há como negar que a obra literária expóe, por meio de toda a estética utilizada, o pensamento de determinado grupo social a respeito de determinado elemento.

Em outras palavras, a proposiçáa de Candido aponta para a necessidade de náo reduzir a análise apenas à estética literária ou a seus aspectos sociais, mas, sim, considerar ambas, já que é por meio da técnica de escrita própria da literatura que o fator histórico-social se torna presente na obra. Partindo desta perspectiva, é possível pensar, também, na noção de literatura de fronteira ${ }^{4}$, segundo a qual há textos literários que tendem a se aproximar mais do contexto, sem abandonar a ficção narrada. Tratar-seiam de subgêneros no limiar entre ficção e realidade. O exemplo utilizado por Ginzburg é a obra $A$ Utopia, de Thomas More. Segundo o autor, poder-se-ia destacar duas faces do livro: os elementos sérios e os elementos cômicos. Nesse sentido, é possível dizer que o contexto é contemplado de um ponto de vista insólito, a partir do que o historiador chama de rituais de inversão: More imaginou uma sociedade fictícia, uma realidade às avessas, para, então, inserir uma tese social, utilizando-se do mito, do inventivo.

Sob esta mesma lógica utilizada por Ginzburg, pode-se colocar a crônica como um gênero de fronteira ${ }^{4-5}$, já que ela se utiliza da estética essencialmente literária para contar os fatos acontecidos, que devem ser contemplados no jornal. E, mais do apenas contar os fatos ocorridos no futebol, pensando no caso específico de Nelson Rodrigues, a crônica figurava como um meio de disseminar a tese de que o futebol era símbolo de uma identidade nacional, representada também pelo negro e pelo mestiço. E tudo isso, sem romper com a ficção típica das técnicas de escrita da literatura.

Quanto à apresentação dos resultados, por se tratar de um artigo de cunho histórico e, portanto, sem resultados absolutos, tampouco objetivos, esta se dará por meio da discussão das fontes, sendo retomada ao fim do texto.

\section{O leitor Nelson Rodrigues}

Nelson, embora não gostasse do epíteto, era um erudito. Assim como Mario Filho - seu irmão mais velho e uma referência no jornalismo esportivo -, era um leitor ávido desde a infância. Em se tratando de leitura era bastante eclético: lia autores dos mais variados gêneros e escolas - da poesia parnasiana à própria crônica esportiva, do conto modernista ao romance naturalista. E não era só: tinha lido também os clássicos da literatura mundial, e alguns autores da filosofia, sociologia e história ${ }^{6}$.

Além da leitura, entendia e citava outros tipos de arte e entretenimento, como a pintura (gostava de Michelangelo); a televisão (um dos seus principais interlocutores era o humorista Jô Soares, que na época tinha o programa $O$ Planeta dos Macacos); o cinema - obsessivamente citava o filme Love Story, que, segundo o literato e teatrólogo, fez o brasileiro aprender a chorar, e Ben Hur (sempre que um atleta fazia um esforço físico exagerado era um "remador de Ben Hur") ${ }^{7-9}$; a música - conhecia do samba ao clássico (volta e meia se referia aos europeus com wagnerianos), mas tinha especial predileção por óperas, chegando até a escrever um período sobre elas; e, sobretudo, o teatro, por motivos evidentes ${ }^{10}$.

Mas, o conhecimento de Nelson, era pautado também na cultura oral. Como o período e o ambiente em que vivia favoreciam o convívio com outros intelectuais e $\operatorname{artistas}^{11}$ (p.97-142), Nelson sabia de forma excepcional usar do informal contato com essas pessoas para construir seus textos. Uma frase de impacto numa conversa de bar, uma declaraçáo numa crônica, uma conversa por telefone, uma história contada por um terceiro, tudo servia de inspiração para que Nelson construísse os seus textos ${ }^{6}$.

Este complexo quadro de influências - embora o termo influência não exprimisse exatamente o que ocorria nas crônicas de Nelson, já que este usava das suas leituras para metaforizar situações do cotidiano 
do futebol e, muitas vezes, acabava inserindo a fonte na sua própria dramatização, modificando sua essência ${ }^{12}$ - pode ser estruturado em quatro tipos: 1 ) a referência aos clássicos da literatura mundial; 2) aos clássicos da literatura nacional; 3 ) as citaçôes de filósofos e sociólogos ou outros tipos de intelectuais ligados ao campo acadêmico e artístico; 4) os diálogos e brincadeiras com amigos intelectuais. Cada um destes tipos tinha características próprias.

1) Nelson tinha especial predileção pela leitura dos clássicos da literatura mundial. E seus autores eram usados, regularmente, como componentes das metáforas referentes à situação nacional. Com essa função, citou nas suas crônicas, por exemplo, Goethe, Vitor Hugo, Kafka, Eça de Queirós e seu clássico Os Maias, bem como a tradicional obra que guarda a tradição oral dos povos persa e indiano, $A s$ Mil e Uma Noites. Mas tinha especial predileção por dois deles: Proust - "Nós inventamos a lentidão. Se isso fosse, em vez de futebol, literatura, que diria eu? Diria que a morosidade é uma virtude proustiana do craque do Brasil. [...] O brasileiro é lento, porque precisa fazer beleza"8 (p.182) - e Dostoievski, seu escritor preferido.

2) Quanto à literatura nacional, a situação era diferente. Nelson tinha apreço por escritores que acreditavam no Brasil como o país do futuro, no povo brasileiro como um modelo vitorioso e nos que tentavam criar um modelo literário genuinamente brasileiro; usava-os, então, como exemplos a serem $\operatorname{seguidos}^{13}$ (p.245-73). Os principais: Olavo Bilac, um admirador da prática esportiva, embora Nelson acentuasse regularmente que não queria "quebrar lanças em prol do estilo, como queria Bilac"7 (p.89); Euclides da Cunha, citado por impor em Os Sertóes drama à condição do homem brasileiro ${ }^{7, b}$ (p.96); e José do Patrocínio (vale lembrar que Nelson havia conhecido Patrocínio Junior na redaçáo do jornal do seu pai), evocado quando era necessário demonstrar a obstinaçáo do povo brasileiro, traçando um paralelo com temas que estavam em voga no início do século. Como nesta passagem, em que Nelson cita José do Patrocínio e este, na imaginação do cronista, citava Shakespeare.

Cada um de nós é um pouco como o Zé do Patrocínio. O "Tigre da Abolição" era suscetível às mais cavas e feias depressōes. Sua retórica sempre começava fria, gaguejante. Seus amigos, porém, iam para o meio da massa e começavam a berrar: - "Negro burro, negro analfabeto, negro ordinário!". E, então, Patrocínio pegava fogo. Dizia coisas assim: - "Sou negro, sim. Deus deume sangue de Otelo para ter ciúmes de minha pátria”. Para assumir a sua verdadeira dimensão, o escrete precisava ser mordido pelas vaias. Foi toda uma maravilhosa ressurreição.

Pelé, maravilhosamente negro, poderia erguer o gesto, gritando: - "Deus deu-me sangue de Otelo para ter ciúmes da minha pátria”. E assim, brancos ou pretos, somos 90 milhões de Otelos incendiados de ciúme pela pátria ${ }^{8}$ (p.159-60).

Em contrapartida, usava normalmente da sátira, da crítica ou do desdém em relação aos que, explicitamente, espelhavam-se no modelo europeu ou que tratavam o homem brasileiro de forma pejorativa ${ }^{7-8}$. Machado de Assis, o mais citado, era tratado, embora sempre com uma conotaçáo de respeito, como um melancólico nacional, admirador do inglês ${ }^{7, c}$ (p.83). Como no excerto em que, sutilmente, mencionava o pessimismo de Machado: "Não somos os melhores', afirma um cronista machadiano"7 (p.165).

Em última instância, citava escritores completamente fora de contexto. Ou apenas para dar graça à crônica, como em uma partida sem muita emoção, na qual relatava que esta havia terminado, "[...] como diria Augusto dos Anjos, num abominável empate" $8, \mathrm{~d}$ (p.88). Ou para criar um quadro metafórico: "E, então, num exílio de Gonçalves Dias, o time nacional vai comer e beber a bola" (p.107).

3) Já sobre as citaçóes dos intelectuais e dos acadêmicos reconhecidos, eram os casos em que Nelson menos esboçava afeto ou complacência. Apesar de ter lido, ou pelo menos conhecido os escritos dos vultos da "intelligentsia" nacional e mundial, o cronista se posicionava nitidamente contrário aos grandes modelos teóricos/explicativos que, segundo ele, pouca utilidade tinham para o povo ${ }^{6}$. Assim pensava em relação à filosofia marxista:

[...] Sartre, o grande Sartre, andou por aqui e disse coisas de que se envergonharia [...]. Podia dizê-las, porque era Sartre. Por exemplo, afirmou o grande homem: - "o marxismo é inultrapassável". [...] daqui a quinze minutos, o marxismo pode estar ultrapassado por coisa muito melhor ${ }^{7}$ (p.173).

Do mesmo modo em relaçáo à psicanálise freudiana. Ontem, o meu fraterno colega entrevistou uma psicanalista [...].

Mas a psicanalista começa a falar e logo percebemos o seu raro brilho e o seu vasto saber. [...]. E eu então vi subitamente tudo. Imaginei que, diante de uma prova de natação, a psicanalista havia de concluir: - "Quem nada é a piscina e não o nadador". Mas minha vontade foi de bater o telefone para a TV Globo e dizer: - "Minha senhora, não se esqueça do nadador" (p.108-9). 
Às vezes, conjugando as duas teorias para, sem o menor pudor, criar um estereótipo e satirizá-las. Como nesta criativa passagem, em que até a obra de Erasmo de Roterdã torna-se parte da formulação de Nelson.

Descobri, então, que o idiota morto é solene, hierárquico, como um defunto real. Mas eis o que eu queria dizer: - já fizeram o elogio da loucura e ninguém se lembrou ainda de fazer o elogio, muito mais procedente da burrice. Vejam vocês: - o Sexo tem o seu Freud, a Economia tem o seu Marx. E ninguém observou o óbvio, ou seja: - que a burrice influi mais no comportamento humano do que o fator sexual, ou econômico ou outro qualquer ${ }^{8}$ (p.91).

Raros eram os casos em que elogiava, ou ao mesmo citava o teórico (geralmente um filósofo ou sociólogo) de maneira imparcial ou simpática ${ }^{7-9,14}$. O próprio Sartre, em passagem pelo Brasil, levantou uma questão que causou admiraçáo em Nelson. Os homens de cor no Brasil vivem tão mal que justificam a pergunta que aqui fez Jean-Paul Sartre: - “E os negros? Onde estão os negros?”. Realmente, ele não vira um único preto na seletíssima platéia de suas conferências. E, realmente, nunca se viu um preto brasileiro vestido de casaca, numa recepção do Itamaraty. Pelé é uma exceção violenta. Todas as casacas do Brasil deviam vesti-lo ${ }^{8, f}$ (p.167).

Com a exceção única de Gilberto Freyre, o qual acentuava apoio ao modelo teórico formulado ${ }^{15-17} \mathrm{e}$ uma nítida afeição pessoal, materializada, inclusive em alguns prefácios ${ }^{18}$, Nelson Rodrigues deixava claro que era preconceituoso em relação ao grupo de intelectuais brasileiros. Inclusive, uma de suas iniciativas era tentar diferenciar estes intelectuais do povo. Sendo uma das suas estratégias literárias, exatamente afirmar que intelectual não gostava de futebol - ou seja, para o cronista, seriam estes tipos os verdadeiros alienados ${ }^{7-8}$.

O teatrólogo não poupou nem seus próprios pares da arte teatral ao afirmar que, volta e meia, faltava mais futebol ao teatro brasileiro para que este aprendesse o que era um verdadeiro drama ${ }^{6}$. Assim, se sugeria aos escritores de peças teatrais uma maior utilização do futebol como tema, e náo raro o esporte aparecia em algum diálogo, nas suas próprias peças, ou mesmo como fio condutor da trama. O pequeno trecho de $A$ Falecida - peça que levou o futebol ao Teatro Municipal do Rio de Janeiro - serve como exemplo:

OROMAR - Vais ao jogo domingo? (Simultaneamente com o diálogo dos dois, há uma discussão patética entre os outros parceiros).
PARCEIRO No 1: - O Carlyle nunca foi jogador de futebol!

TUNINHO - E tu achas que eu vou perder um jogão daqueles?

PARCEIRO No 2o - Quem? O Carlyle ensopa

Pavão!

OROMAR - Para o teu governo - o Fluminense vai dar um banho. Nem, se discute!

PARCEIRO No 1: Jogador profissional que me perdesse um pênalti, eu multava!

TUNINHO - Pimba! Sou Vasco e dou dois gols de vantagem!

OROMAR - Você é uma besta!

PARCEIRO No 1 - Entendo muito mais de

futebol que você!

TUNINHO - Queres apostar?

PARCEIRO No 1o - São uns palhaços!

OROMAR - O Ademir joga?

PARCEIRO No 2 - Vocês ganharam no apito! ${ }^{19}$ (p.98-9).

4) Os cronistas, literatos e outras personalidades que Nelson prezava e faziam parte do seu círculo de relacionamento, inclusive alguns poucos contrários ao seu típico otimismo em relação à nação e ao futebol, eram mencionados de maneira afetuosa. Mesmo as divergências eram tratadas de maneira amistosa, geralmente através de uma sátira sutil ${ }^{\circ}$ (p.14-5). Entre outros, Nelson mencionava, com mais frequência, fazendo questão de acentuar a amizade: Antônio Callado (escritor), Walter Clark (diretor de TV), Candido Portinari (pintura), Hugo Carvana (ator e diretor), Manuel Bandeira (poeta), Cláudio Mello e Castro (jornalista), Paulo Francis (jornalista), Walther Moreira Salles - que, segundo Rodrigues ${ }^{7}$, na brincadeira, era um dos maiores salários do Brasil, mas contava com a sua admiraçáo porque deu apoio financeiro ao desacreditado escrete que iria disputar a Copa do Mundo do México em 1970. Mas seus maiores elogios e diálogos, sem dúvida, eram com José Lins do Rego, Armando Nogueira e Gilberto Freyre (o único formulador de uma tese sociológica aceita por Nelson Rodrigues) e, sobretudo, seu irmão Mario Filho - o qual era insistentemente definido pelo próprio teatrólogo como mentor intelectual.

Gostava mais de citar o contato pessoal, os diálogos, os encontros, as histórias e causos a respeito dos mesmos do que propriamente citar os seus textos. Mas tinha um em especial que Nelson citava quase que obsessivamente - "[...] como todo cronista, eu tenho o meu boi de Túnis [fazendo analogia à obra Os Maias de Eça de Queirós]. Ele se chama Otto Lara Resende" (p.100). Sabendo que o escritor não 
se interessava por futebol, Nelson Rodrigues vivia questionando a sabedoria do amigo, como numa passagem onde dizia que no único jogo que o amigo assistiu, questionava: "- Quem é a bola?”" (p.88).

Notando que o escritor mineiro não gostava das suas brincadeiras, Nelson Rodrigues chegou até a intitular uma de suas peças de Otto Lara Resende ou Bonitinha, mas ordinária ${ }^{6}$ (p.325-8). Com a mesma função provocativa, Nelson escreveu certa vez:

Amigos, já contei o episódio. Certa noite, num sarau de grã-finos, o Otto Lara Resende cheira a bombinha de asma e declara o seguinte: - "O mineiro só é solidário no câncer”. As senhoras presentes entreolharam-se, delicadas. Os cavalheiros não souberam, de imediato, se aquilo era piada torpe ou fina sociologia. Os mais atilados veriam, ali, uma verdade estadual, inapelável e eterna. A frase do Otto caiu na boca do povo. Todo o Brasil a repete. [...] Há quem diga que a frase são as obras completas do escritor. Seja como for, continua de pé a dúvida: - piada ou verdade? ${ }^{7, g}$ (p.98).

Somados os seguintes fatos: uma produção regular por décadas, a obsessividade ao tratar os temas e a significativa popularidade, pode-se deduzir que Nelson contribuiu substancialmente para a popularização da literatura nacional e mundial, das teorias explicativas (embora quase sempre criticadas) e dos seus próprios pares. E tinha plena consciência disso...

\section{A dramaturgia na crônica esportiva}

Se a crônica, como indica Antonio CANDIDO ${ }^{2}$, é um gênero híbrido, situada entre a fronteira do real - o cotidiano, de onde, com esmero, o escritor retira seus temas - e da ficção - pois o escritor, usando-se da criatividade, constrói e desconstrói as informações obtidas no dia-a-dia -, pode-se acentuar que Nelson Rodrigues se situaria, e bem consciente disso, mais próximo à segunda, ou seja, da fantasia criativa que o literato, um artista, pode usufruir.

Ora, se Nelson conseguia transformar seus próprios pares da crônica e das artes, pessoas públicas e com inserção nos meios de comunicação de massa, em indivíduos completamente caricatos (como se fossem atores de uma peça teatral), não foi nada difícil que os personagens fictícios, frutos da imaginação do autor de $A$ Falecida, se tornassem também figuras conhecidas entre o segmento da população que acompanhava o futebol no Brasil - portanto uma parcela significativa do país ${ }^{13}$. Não eram muitos, pois uma das estratégias literárias de Nelson para a popularização dos personagens - fossem eles reais ou não - era a repetição exaustiva.

Tinha o Sobrenatural de Almeida, figura invisível que influía das mais diferentes formas no resultado de uma partida, sem sequer ser percebido: “[...] o Armando Marques marcou um pênalti fantástico. Não houve nada, absolutamente nada. Mas o Sobrenatural de Almeida soprou no ouvido do árbitro: - 'Pênalti, pênalti!'. Armando foi na conversa e apitou a penalidade"8 (p.139). Também semelhante ao Sobrenatural, ou seja, não pertencendo ao plano terreno, existia o Gravatinha. A diferença era que enquanto o primeiro agia sem uma lógica específica (dizia Nelson que ele gostava de perseguir o líder do campeonato), o segundo era um torcedor fervoroso, sempre a ajudar o seu clube, o Fluminense - "Desde seu falecimento, em 1918, o 'Gravatinha' só baixa do Além para ver as vitórias do Fluminense” (p.210). Volta e meia, os dois se confrontavam, mas como Nelson era torcedor do Fluminense, "[...] não há dúvida de que, nas brigas, sente-se à interferência do Sobrenatural de Almeida na estúpida tentativa de comprometer o triunfo tricolor. Mas o torpe indivíduo sempre perdeu para o nosso venerado e falecido 'Gravatinha"',i, (p.214).

Existiam outros que eram menos extraordinários. A Grã-fina de Narinas de Cadáver, senhora que pouco entendia de futebol (com todo membro da elite para Nelson), tanto é que quando, raramente, comparecia ao Maracaná, assim como Otto Lara Resende, vivia perguntando a todos: "quem era a bola?" ",j (p.141). Desdenhava o futebol, mas sempre que a seleção brasileira fazia grandes jogos aparecia, comemorando sem fazer cerimônia. Como na conquista da Copa do Mundo de 1970, por exemplo: "Eu vi a grã-fina das narinas de cadáver cair de joelhos, no meio da rua, e estrebuchar como uma víbora agonizante" (p.171). Também os Paralelepipedos, que eram numerosos, normalmente populares que pouco conheciam de futebol e interagiam com Nelson de alguma forma. Como no exemplo a seguir:

Estão me chamando no telefone: volto já. Demorei dois minutos. Era o paralelepípedo. Queria me dizer apenas o seguinte: - "O Fluminense é um time sem esquemas, joga sem esquema”. Disselhe eu: - "Está certo e Deus é grande. Antes de desligar, ele me disse: - "O meu nome completo é Paralelepípedo de Albuquerque. Tchau”. Assim se despediu ${ }^{9, \mathrm{k}}$ (p.124).

Evidentemente, os criativos personagens de Nelson, importantes na formulação de um enredo para o futebol brasileiro ${ }^{20}$, tinham um inimigo em potencial: "[...] os idiotas da objetividade querem duvidar 
do 'Gravatinha' e do Sobrenatural de Almeida. E, no entanto, não cabe nenhum sofisma" ",1 (p.218).

Ainda reforçando que a crônica de Nelson era a mais próxima da arte, eram comuns também, além dos personagens fictícios, os sentidos figurados de linguagem - "Sem um mínimo de sorte, o sujeito não consegue nem atravessar a rua" ${ }^{\prime, m}$ (p.143). Assim como a sorte, tinha o picolé Chicabon (a maior delícia do mundo, segundo o autor), a bola (que algumas vezes falava), a carrocinha de cachorros (que poderia capturar a qualquer hora um brasileiro com complexo de vira-latas), entre vários outros termos.

São hipérboles, onomatopeias, mas, principalmente, metáforas ${ }^{20}$ (p.159-85). Recursos que somados serviam para criar um estilo próprio de fazer crônicas. Mesmo considerando que existe uma relativa autonomia artística do autor ao criar sua obra ${ }^{3}$, são muito comuns as semelhanças entre a produção dentro de um mesmo gênero, pois o contexto social bastante específico e a especialização em um determinado assunto colaboram na aproximação de tais textos $^{2}$. Só que Nelson Rodrigues fugia à regra. Seu estilo polêmico, ousado, plástico, obsessivo e exagerado nunca permitiu que nada parecido fosse criado.

Este estilo que exacerba a autonomia do artista ocorre, evidentemente, por alguns motivos de cunho pessoal, social, profissional, econômico e político, todos fundidos na história de vida do autor. Assim, paradoxalmente, mesmo a autonomia literária pode ser inserida em determinada conjuntura, coadunando-se, então, ao que CANDIDo ${ }^{3}$ define como a fusão de texto e contexto.

Nelson cresceu em um meio que estimulava a leitura e a produção textual. Foi inserido de modo prematuro no meio jornalístico, em que rapidamente conheceu os bastidores da notícia ${ }^{13}$ (p.207-10). Inicialmente, foi trabalhar como jornalista policial e tinha uma especial predileção pelos casos de suicídios de namorados ou amantes - muito comuns nas primeiras décadas do século XX, em virtude das rígidas normas de uma sociedade acentuadamente conservadora. Foi quando começou a usar da criatividade para desenvolver enredos literários acerca do motivo dos crimes, geralmente criava paixóes impossíveis com pactos de morte ${ }^{6}$ (p.73-100).
Seu caráter obsessivo fez com que fossem estes temas - a saber: a paixão, o sexo, o adultério, o conservadorismo e a morte - trabalhados na adolescência, nos jornais populares de propriedade do seu pai, Mario Rodrigues, o conteúdo base de todas as suas peças teatrais, bem como dos folhetins e crônicas do cotidiano (poder-se-ia defini-las melhor como crônicas eróticas, mas era uma conotação inadequada para época em que viveu), como a popularíssima A Vida Como Ela É... ${ }^{22}$

Mas existia outro forte influenciador na produção de Nelson Rodrigues: o maior trauma da vida dos Rodrigues iria também ter reflexos sensíveis, principalmente nas suas peças teatrais. A característica populista dos periódicos da família Rodrigues - como as notícias de adultérios sem uma criteriosa investigação jornalística - acabou sendo o motivo do assassinato passional do talentoso Roberto, um dos seus irmãos mais velhos ${ }^{14}$ (p.21-24). Roberto era cartunista de jornal e pintor. Suas principais obras, em tons de preto e branco, com morbidez e um tom sensual, expunham traição, infidelidade, assassinatos e erotismo.

Entáo, não pode ser mera coincidência que os temas das primeiras crônicas escritas por Nelson Rodrigues e das telas do irmão Roberto sejam exatamente os mesmos das suas peças teatrais e dos demais textos que náo fossem sobre o futebol ${ }^{6}$ (p.346). O teatrólogo sempre manifestou ojeriza pela psicanálise, porém, isto ocorreu porque foram várias as tentativas de explicar o conteúdo das suas obras a partir dos seus traumas de infância/adolescência.

Nelson nunca escondeu sua predileção por fazer teatro em relação aos demais trabalhos nas redaçóes de jornais. Era notório que a escrita jornalística tinha amarras de mais para a criatividade dele. Entretanto, como já descrito, o teor polêmico das suas peças teatrais quase sempre lhe causava problemas com a censura, já que a maioria da sua produção foi concebida em um período de forte repressão sócio/política/artística e de um conservadorismo rigoroso, de tradicionais (católicos) valores familiares ${ }^{23}$. Neste contexto, Nelson Rodrigues chegou a ficar durante anos com várias peças proibidas, restritas, vetadas ou embargadas, ou seja, sem poder contar com elas para o seu sustento. Mas as crônicas futebolísticas, onde se encaixam neste quadro? 


\section{Resultados e discussão}

Em algumas oportunidades, Nelson Rodrigues se manifestou, deixando claro que se saturava, não do futebol, mas do meio jornalístico que era responsável por cobrir os esportes ${ }^{20}$ (p.131-8). Era um torcedor apaixonado pelo Fluminense e - ao contrário do irmão Mario Filho, que nunca manifestou publicamente uma preferência clubística - sempre deixou isto explícito nas suas crônicas ${ }^{9}$, mesmo sabendo que seria criticado por ser tendencioso.

Por desventuras da época, não teve possibilidade de se dedicar exclusivamente às peças teatrais nem à escrita de romances, embora esta fosse a sua vontade. Então, ao mesmo tempo em que a crônica futebolística foi o principal meio de sustento da sua família, provavelmente guardava certo ressentimento por não poder se desvincular desta, quando se sentia incomodado, principalmente com seus pares - "Amigos, o cronista esportivo é, por excelência, o insatisfeito. Para ele, o jogo sempre foi 'tecnicamente falho'. Se ele, em vez de crítico de futebol, o fosse de arte, havia de dizer que Miguel Ângelo 'promete'”, (p.42). E foram várias vezes, tanto é que, passados alguns anos escrevendo crônicas esportivas, Nelson Rodrigues passou a se referir na terceira pessoa (ele ou eles) quando o assunto era a própria crônica esportiva.

E esta condiçáa de priorizar o teatro teve alguns reflexos nas crônicas futebolísticas. $\mathrm{O}$ primeiro era que - novamente agindo de maneira divergente da conduta do irmão Mario Filho, seu maior influenciador - Nelson Rodrigues pouco se engajou de maneira prática no desenvolvimento do esporte. Quer-se dizer que, embora tivesse um compromisso fiel com as formulaçóes teóricas do seu irmão Mario Filho acerca da brasilidade no futebol ${ }^{24}$ - inclusive contribuindo com a ideia original da associação exacerbada entre o escrete e à nação, além de ser fundamental no processo de difusão, pois era o mais popular e foi o mais longevo -, dificilmente se envolvia com questóes de ordem organizativas, mesmo que fossem ligadas diretamente ao Fluminense.

O segundo aspecto é que, ressentido por ser impossibilitado de se dedicar efetivamente ao teatro, Nelson Rodrigues iria transformar o futebol em drama teatral ${ }^{13}$ (p.210-7). Os jogos e os campeonatos, nas suas crônicas, são transformados em enredos. Os jogadores, dirigentes e torcedores, por sua vez, em personagens - ora heróis, ora vilóes. Os únicos que tinham o posto perpétuo de vilóes eram os próprios cronistas esportivos - os entendidos e idiotas da objetividade.
Prova maior de que o futebol era uma encenação na concepção de Nelson Rodrigues, era que, mesmo tendo um amplo repertório de eventos cotidianos que lhe poderiam servir de tema, obsessivamente, como nas peças teatrais, iria permanecer focado nos mesmos assuntos ${ }^{14}$ (p.25-7). E esta insistência em determinados assuntos iria fazer com que suas ideias e criações se tornassem populares, a ponto de serem citadas até a atualidade, como no caso do Sobrenatural de Almeida, ainda usado para explicar algum lance ou resultado inesperado ${ }^{25}$.

Como prioritariamente focava nas suas peças teatrais, o autor de $A$ Falecida, guardava um silêncio específico: em relação à política. Além da lembrança da infância, a de que o seu pai e toda a família tiveram vários problemas por causa do envolvimento político, Nelson Rodrigues, gradativamente, por causa das suas polêmicas peças teatrais, passou a ser estereotipado como um homem depravado, inescrupuloso e sem valores morais, pela parcela conservadora da sociedade brasileira. Desta forma, arranjou querelas com políticos moralistas e, consequentemente, com a censura ${ }^{6,14}$ (p.15-46).

Não querendo aumentar a dimensão do problema e, posteriormente, tentando até atenuá-lo, evitou mencionar questôes políticas nas suas crônicas futebolísticas ou, nas raras oportunidades que discorreu sobre o assunto, manifestou até certa simpatia pelo sistema vigente - como durante boa parte do Regime Militar ${ }^{13}$. Evidentemente, tinha seus motivos: acreditava que as manifestações contrárias à gestão militar eram promovidas por uma elite estudantil/ intelectual que pouco se preocupava com o desenvolvimento da pátria e estava seguindo uma moda: ser de esquerda e falar em Fidel, Cuba e União das Repúblicas Socialistas Soviéticas.

Há um momento, todavia, em que todos se lembram do Brasil, em que 90 milhôes de brasileiros descobrem o Brasil. Aí está o milagre do escrete. Fora as esquerdas, que acham o futebol o ópio do povo, fora as esquerdas, dizia eu, todos os outros brasileiros se juntam em torno da seleção. É, então, um pretexto, uma razão de auto-estima. E cada vitória compensa o povo de velhas frustraçōes, jamais cicatrizadas ${ }^{7}$ (p.181).

Em última instância, sobre as crônicas esportivas de Nelson, frisa-se que a fonte de influência (e inspiração) era o próprio teatro dramático do autor. Mas, para que isso ocorresse, eram necessários os enredos, os personagens, os cenários, os produtores e 
até mesmo o narrador (o próprio Nelson Rodrigues, que, constantemente, também figurava como personagem das suas próprias crônicas), reforçando a tese de Ginzburg ${ }^{4}$ de que a literatura é composta de uma série de diálogos que são - ora sutil, ora evidentemente - expostos pelo escritor. Nelson Rodrigues é o exemplo típico de que nenhuma ilha é uma ilha.

\title{
Notas
}

a. A biografia de Nelson Rodrigues escrita em 1992, por Ruy Castro, traz o título de "O Anjo Pornográfico" - como se autodenominava o próprio Rodrigues em algumas de suas crônicas de memórias publicadas em "O Globo" - em referência a seus escritos com uma forte marca de tragédia e desvios de cunho sexual, que localizavam o autor entre o maldito e a genialidade.

b. Originalmente: Beijos imaculados. O Globo, Rio de Janeiro. 23 jun. 1962.

c. Originalmente: Um horizonte de chifres. O Globo, Rio de Janeiro. 5 jun. 1962.

d. Originalmente: O Otto Banqueiro. O Globo, Rio de Janeiro. 20 dez. 1963.

e. Originalmente: Jogador escalado pelo óbvio. O Globo, Rio de Janeiro. 10 jun. 1966.

f. Originalmente: Elogio da burrice. O Globo, Rio de Janeiro. 2 jun. 1965.

g. Originalmente: O Mineiro Solidário. O Globo, Rio de Janeiro. 27 mar. 1963.

h. Originalmente: O doce "Gravatinha" e o abominável sobrenatural de Almeida. Jornal dos Sports, Rio de Janeiro. 10 nov. 1967.

i. Originalmente: Sobrenatural de Almeida perde para o "Gravatinha”. Jornal dos Sports, Rio de Janeiro. 21 nov. 1967.

j. Originalmente: Um Escrete de Feras. O Globo, Rio de Janeiro. 14 abr. 1969.

k. Originalmente: Paralelepípedo de Albuquerque. O Globo, Rio de Janeiro. 28 jul. 1975.

1. Originalmente: Samarone, Sâmara ou Samura. Jornal dos Sports, Rio de Janeiro. 6 jul. 1967.

m. Originalmente: Zezé em Casa. Jornal dos Sports, Rio de Janeiro. 21 jul. 1960.

n. Originalmente: Maravilhoso Triunfo. Ilustração. Jornal dos Sports, Rio de Janeiro. 15 set. 1959.

\begin{abstract}
Nelson Rodrigues, reader and writer: "dialogues", creativity and erudition expressed in football chronicles

The objective of this research is to reveal the interferences from other genres worked by Nelson Rodrigues, which have a minor relation with the truth - specifically theater - in theses about football, built in sport chronics by the writer. It also aims to expose the sense that Nelson used these resources in his texts about football, as well as the various forms of influences from the reading of classic world and national literature; or even the implicit references to philosophers, sociologists and, also, the intellectual friends, with whom he used to dialogue. To this end, it was analysed the chronic and script of Nelson Rodrigues, based on the theory of Antonio Candido, about the treatment of literature as a source, intersecting the text (author's autonomy and elements of art) and the context of the work.
\end{abstract}

KEY WORDS: Football; Literature; Intertextuality; Sports chronicle.

\section{Referências}

1. Souza MFPSF. Nelson Rodrigues: inventário ilustrado e recepção crítica comentada dos escritos do anjo pornográfico [tese]. Rio de Janeiro (RJ): Universidade Federal do Rio de Janeiro, Faculdade de Letras; 2006.

2. Candido A, Meyer MM, Lopez TAPA. A crônica. Campinas: Editora UNICAMP; 1992.

3. Candido A. Literatura e sociedade: estudos de teoria e história literária. São Paulo: Queiroz; 2000. 
4. Ginzburg C. Nenhuma ilha é uma ilha: quatro visões da literatura inglesa. São Paulo: Companhia das Letras; 2004.

5. Capraro AM. Identidades imaginadas: futebol e nação na crônica esportiva brasileira do século XX [tese]. Curitiba (PR): Universidade Federal do Paraná, Departamento de História; 2007.

6. Castro R. O anjo pornográfico. São Paulo: Companhia das Letras; 1992.

7. Rodrigues N. À sobra das chuteiras imortais. São Paulo: Companhia das Letras; 1993.

8. Rodrigues N. A pátria em chuteiras. São Paulo: Companhia das Letras; 1994.

9. Rodrigues N. O profeta tricolor: cem anos de Fluminense. São Paulo: Companhia das Letras; 2002.

10. Facina A. Santos e canalhas: uma análise antropológica da obra de Nelson Rodrigues. São Paulo: Civilização Brasileira; 2004.

11. Pratt M, Vescio LE, Santos PB. Literatura \& história: perspectivas e convergências. Bauru: Edusc; 1999.

12. Lima LC, organizador. Teoria da literatura e suas fontes. Rio de Janeiro: Civilização Brasileira; 2002.

13. Antunes FMRF. "Com brasileiro não há quem possa”: futebol e identidade nacional em José Lins do Rego, Mário Filho e Nelson Rodrigues. São Paulo: UNESP; 2004.

14. Rodrigues N. O baú de Nelson Rodrigues. São Paulo: Companhia das Letras; 2004.

15. Freyre G. Prefácio. In: Rodrigues Filho M. O negro no futebol brasileiro. 2a ed. Rio de Janeiro: Civilização Brasileira; 1964.

16. Freyre G. Sobrados e mocambos. Rio de Janeiro: José Olympio; 1968.

17. Freyre G. Casa-grande \& senzala. Rio de Janeiro: Record; 1999.

18. Freyre G. Nelson Rodrigues, escritor. In: Rodrigues, Nelson. O reacionário: memórias e confissóes. Rio de Janeiro: Record; 1977. [citado 25 maio 2004]. Disponível em http://prossiga.bvgf.fgf.org.br/portugues/obra/prefacios_p_terceiros/nelson.htm.

19. Rodrigues N. A falecida. In: Pedrosa M. Gol de letra: o futebol na literatura brasileira. Rio de Janeiro: Gol; 1968.

20. Marques JC. O futebol em Nelson Rodrigues. São Paulo: EDUC/FAPESP; 2000. p.131-8, 159-85.

21. Chiappini L, Bresciani MS. Literatura e cultura no Brasil: identidades e fronteiras. Sáo Paulo: Cortez; 2002.

22. Rodrigues N. A vida como ela é... São Paulo: Companhia das Letras; 1992.

23. Caldeira J, Carvalho F, Marcondes C, De Paula, SG. História do Brasil. São Paulo: Companhia das Letras; 1999.

24. Rodrigues Filho M. O negro no futebol brasileiro. 4a ed. Rio de Janeiro: Mauad; 2003.

25. Andrade EG, (Tostấo). O anjo pornográfico. Folha de S.Paulo, São Paulo. 4 abr. 2005. [citado 6 ago. 2005]. Disponível em: www.lainsignia.org/2005/abril/cul_010.htm.

\begin{tabular}{r|l} 
ENDEREço & \\
Natasha Santos & \\
Departamento de Educação Física & Recebido para publicação: 24/04/2013 \\
Setor de Ciências Biológicas & 1a. Revisão: 17/09/2013 \\
Universidade Federal do Paraná & 2a. Revisão: 10/11/2013 \\
R. Coração de Maria, 92 - Jd. Botânico & Aceito: 23/02/2014 \\
80210-132 - Curitiba - PR - BRASIL & \\
e-mail: nata.shas@ig.com.br &
\end{tabular}

